\title{
Impact of Entrepreneurship Development Programme on Value addition of Millets Products for the Higher Income Generation of SHG
}

\author{
M. Vimalarani* and P.R. Nisha
}

Krishi Vigyan Kendra, Tamil Nadu Veterinary and Animal Sciences University, Kattupakkam, Kancheepuram District, Tamil Nadu, India

*Corresponding author

\section{Keywords}

EDP, Enterprise, Millets, Packaging

\section{Article Info}

Accepted:

05 June 2020

Available Online:

10 July 2020

\section{A B S T R A C T}

Entrepreneurship is a critical tool for socio-economic development and facilitating rural economic development, which is becoming increasingly needed to respond to the growing impacts of accelerating climate change on rural women's livelihoods in less developed countries. Millets are highly nutritious and provide important nutrients such as niacin, magnesium, potassium, manganese, iron and phosphorous. They also contain higher amount of protein with essential amino acids, fibre and vitamin E. In the present study efforts has been made to study the awareness and impacts of adopting millets products as income venture for SHG women in Kancheepuram District. Food products developed were analysed for nutritional qualities, sensory attributes and keeping quality. It was observed that all the products were highly accepted by the taste panellists in terms of texture, taste and overall acceptability and stored at ambient room temperature upto six months period. Entrepreneurship Development programme enhanced SHG.

\section{Introduction}

Entrepreneurship development (ED) refers to the process of enhancing entrepreneurial skills and knowledge through structured training and institution-building programmes. According to Global Entrepreneurship Monitor (2007), women are key to the development of entrepreneurship in any given society. They also help to eliminate some societal problems through their entrepreneurial activities in informal sectors. Many Institutions are involved in the entrepreneurial development programmes in order to assist the community to start an enterprise (Ahamed and Julion, 2012). Entrepreneurs face many challenges in establishing, running and managing their enterprises. Besides challenges, there are unlimited opportunities for entrepreneurship 
development in the state. Challenges faced by the sampled entrepreneurs are classified as marketing, raw material, and manpower, finance, power, procedural formalities and machinery (Pradhan and Nath, 2012). The environments in which entrepreneurial activities are propagated contribute significantly to the development of private sector. Consequently, conditions that are favourable constitute the bedrock for the survival, growth and competitiveness of entrepreneurship development (UNESCAP, 2012). Availability and access to adequate and sustainable finance therefore is critical for entrepreneurs and small and medium enterprises (SMEs) in view of the fact that the life cycle of businesses require varied needs for cash, taken cognisance of the start-up, growth and transition stages of development. The increasing emphasis on the significance of entrepreneurship as a decisive factor for national development has dovetailed into the search through a wide range of schemes targeted at hastening the tempo of new business activities in the organized private sector (Okpala, 2012). Entrepreneurs identify innovative approach to seize an opportunity, mobilize money and management skills, and take calculated risks to open markets for new products, processes and services. To build and sustain SMEs, the entrepreneur needs to access diverse form of resources such as financial capital, human capital and physical capital with each playing significant but different roles during the life cycle of a new business (Fatoki, 2014).

Millets are highly nutritious and provide important nutrients such as niacin, magnesium, potassium, manganese, iron and phosphorous. They also contain higher amount of protein with essential amino acids, fibre and vitamin E (Balasubramanium, 2013). Finger millet and foxtail millet are several health benefits i.e. finger millet is excellent source of calcium it strengthen bones, maintain blood glucose levels, lowers cholesterol, prevents anemia, relaxation to the body, play important role in losing weight and wound healing (Mathangi and Sudha, 2012). Health benefits of aqueous extract of foxtail millet have excellent anti-hyperglycemic activity (Mamatha et al., 2019). Foxtail millet contains $47 \mathrm{mg}$ polyphenolics/100 g so it acts as antioxidant property. In addition, defatted foxtail millet protein hydrolysates also exhibited antioxidant potency (Mohamed et al., 2012).

Thus, entrepreneurship development helps in alleviating poverty when employment opportunities are created through new entrepreneurial venture start-up or the growth of existing ones. This eventually result in boosting social wealth through the emergence of new market, new industries, new institutional form, new technology and increase in income which result in enhanced living standards for the populace(Patankar and Metha, 2014). As women play an active role in the economy of the families, they are enough to invest money and lead better life. There is a linkage between women's access to independent income and her position in the family. It is believed that when women are provided credit and they take up income generating activities, their income is expected to increase. To give rural women visibility they must get organized into self help groups. Group approach is a viable setup to empower women economically, socially and technologically for better livelihood. Role of SHGs is emerging as promising tool in this context. The SHGs are created to enable the joint responsibility towards self and sustainable development. Geetamma and Bulla (2013) studied that the Micro finance through Self Help Group (SHG) has been recognized internationally as the modern tool to combat poverty and for rural development. Micro finance and SHGs are effective in reducing poverty creating awareness which 
finally results in sustainable development of the nation. This study examines the awareness and impacts of adopting millets products as income venture for SHG women in Kancheepuram District.

\section{Materials and Methods}

KVK, Kattupakkam, Kancheepuram district identified women SHG members during the year 2016-17 for the conduct of EDP on value added Minor millets products. KVK conducted training programmes through EDP mode to Self Help Group women to start a suitable enterprise.

\section{Selection of SHG women}

SHG women who were interested in attending class and wanted to start an enterprise were selected. Women group from Ninnaikattur of Kattankolathur Block, Kancheepuram District were selected for the EDP. Most of the women were housewives and doing household activities and rearing children. Selected 20women were from lower middle class families and from 30 to 35 years of age. Before intervention only three members were doing some activities through SHG such as tailoring. Members were selected based on their interest and involvement in the food processing sector. After getting their family members permission they visited KVK for further progress of the programme.

\section{Interventions}

Conduct of well planned ten classes for the entire period. Home Scientist of KVK, Kancheepuram made an initiative to conduct training programme for SHG women mainly on value addition of millets. The lectures and Hands on demonstration include the following topics.

Lecture on processing and value addition of Millets
Standardization of new millets based products

Demonstration of Millets based ready mixes in the commercial form-

Health mix, Chapathi mix, Adai mix, Iddiyappam/kozhukattai mix, Murukku mix, Uppuma mix, Millets cookie, Iddli/Dosa mix

Imparting latest packaging technologies and Labelling (Designing and preparation of stickers)

Quality control measures and Licensing and branding

Providing marketing facilities and tie up with KVK Rural mart and Weekly Bazaar

\section{Sensory evaluation}

The ultimate aim of any food item is not only to provide nutrients but also to give sense of delight to consumers by virtue of desired colour, flavour, taste, texture and overall acceptability. In order to determine consumer acceptability the products were evaluated by organoleptic quality attributes by ranking the responses using a 5 point hedonic scale sensory evaluation test. The sensory qualities, namely, appearance, texture, flavour, colour and overall acceptability were determined. Sensory evaluation test was carried out among twenty farm women to get the correct point for the acceptability of developed millets based products.

\section{Nutritional qualities}

Nutritional qualities of developed products mainlyproximate principles were assessed in order to improve the quality of the product.

\section{Shelf life of the products}

The shelf life the products were determined by physical method. The products were stored in dry and cool place. Shelf life of products was evaluated using sensory analysis periodically in each three months periodically. Developed products were also 
studied for their storage quality by packing in different packaging materials.

\section{Cost of production}

Cost analysis was carried out in order to market the products. They were taught to calculate the cost of the manufactured products.

\section{Results and Discussion}

The successful entrepreneurial process encompasses developing opportunities, assembly of necessary assets, financial resources, human capital and managing and building operations with the ultimate objective of value creation. The findings of the EDP training given to $\mathrm{SHG}$ women is given below

\section{Sensory profile of millets products}

Sensory attributes of foods are important indicators of acceptability and sustainability of processed foods in the ever growing processed food market. Table I provides the mean sensory profile of the millets products.

All the products were highly accepted by the taste panellists in terms of texture, taste and overall acceptability. The mean acceptability score of the products ranged from 21.2 to 23.7. The acceptability index for Millets cookies was highest (95.6) followed by chapathi flour (95.0), millets health mix (89.4), murukku mix (89), adai mix and upuma mix (88.8), iddli/dosai mix (85.0) and idiyappam/kozhukattai mix (84.8).

\section{Shelf life of the products}

The prepared minor millets products were packaged and stored in poly propylene pouches so as to keep the product safe and clean and to increase shelf life at ambient room temperature. The products were stored in dry and cool place.

The developed product can be stored upto three to six months without any deterioration in different flexible pouches under ambient storage conditions. Food grade pouches provide clarity as well as protection against insect and moisture. Similar observations were reported by Seema et al., (2016) by storage and cooking quality of millet fortified pasta products.

Millets Health mix and chapathi flour can stored upto 12 months at room temperature. Other products such as millets ready mixes can stored upto six months at room temperature, whereas bakery products such as cookies can stored upto one month period.

\section{Nutritional qualities}

The developed millets products were given their nutritional value mainly proximate composition in order to depict in the label. Table II depicts the nutritional information of the millets products.

Protein content of the Millets Health mix was highest $19(\mathrm{~g})$ followed by adai mix $(16 \mathrm{~g})$, chapathi flour (14.4g), iddli/dosai mix and cookies (12g), uppuma mix (11g), murukku mix (10g) and idiyappam/kozhukattai mix (8.3g). With regard to calories millets cookies showed highest amount of $650 \mathrm{kcal}$, where as other products were in the range of $305 \mathrm{kcal}$ to $385 \mathrm{kcal}$.

\section{Economics and cost analysis}

In order to market the products cost analysis was carried out. Table III depicts the Economics and cost analysis of the developed products. 
Table.1 Mean sensory profile of millets products*

\begin{tabular}{|l|c|c|c|c|c|c|c|c|}
\hline Attributes & $\begin{array}{c}\text { Millet } \\
\text { Health } \\
\text { mix }\end{array}$ & $\begin{array}{c}\text { Chapathi } \\
\text { flour }\end{array}$ & $\begin{array}{c}\text { Adai } \\
\text { mix }\end{array}$ & $\begin{array}{c}\text { Idiyappam/ } \\
\text { Kozhukattai } \\
\text { mix }\end{array}$ & $\begin{array}{c}\text { Uppuma } \\
\text { mix }\end{array}$ & $\begin{array}{c}\text { Murukku } \\
\text { mix }\end{array}$ & $\begin{array}{c}\text { Millets } \\
\text { cookies }\end{array}$ & $\begin{array}{c}\text { Iddli/ } \\
\text { Dosai } \\
\text { Mix }\end{array}$ \\
\hline $\begin{array}{l}\text { Colour and } \\
\text { Appearance }\end{array}$ & 4.6 & 4.7 & 4.5 & 4.3 & 4.5 & 4.5 & 4.8 & 4.5 \\
\hline Taste & 4.5 & 4.8 & 4.7 & 4.2 & 4.4 & 4.7 & 4.9 & 4.3 \\
\hline Texture & 4.4 & 4.6 & 4.6 & 4.1 & 4.6 & 4.4 & 4.6 & 4.4 \\
\hline Flavour & 4.3 & 4.8 & 4.2 & 4.2 & 4.3 & 4.6 & 4.7 & 4.3 \\
\hline $\begin{array}{l}\text { Over all } \\
\text { acceptability }\end{array}$ & 4.83 & 4.8 & 4.2 & 4.3 & 4.4 & 4.5 & 4.8 & 4.4 \\
\hline $\begin{array}{l}\text { Mean total } \\
\text { Score }\end{array}$ & 22.37 & 23.70 & 22.20 & 21.20 & 22.20 & 22.70 & 23.80 & 21.90 \\
\hline $\begin{array}{l}\text { Acceptability } \\
\text { Index }\end{array}$ & 89.4 & 95.0 & 88.8 & 84.8 & 88.8 & 89.0 & 95.6 & 85.0 \\
\hline
\end{tabular}

*Five point Hedonic scale

Table.2 Nutritional information (100g) approximate

\begin{tabular}{|c|c|c|c|c|c|c|c|c|}
\hline Nutrient & $\begin{array}{l}\text { Millet Health } \\
\text { mix }\end{array}$ & $\begin{array}{l}\text { Chapathi } \\
\text { flour }\end{array}$ & Adai mix & $\begin{array}{c}\text { Idiyappam/ } \\
\text { Kozhu } \\
\text { kattai mix }\end{array}$ & Uppuma mix & Murukku mix & $\begin{array}{l}\text { Millets } \\
\text { cookies }\end{array}$ & $\begin{array}{c}\text { Iddli/Dosai } \\
\text { Mix }\end{array}$ \\
\hline Protein (g) & 19 & 14.4 & 16 & 8.3 & 11 & 10 & 12 & 12 \\
\hline $\begin{array}{l}\text { Carbohydra } \\
\operatorname{tes}(\mathrm{g})\end{array}$ & 70 & 33 & 55 & 66 & 64 & 60.2 & 72 & 50.6 \\
\hline $\begin{array}{l}\text { Calories } \\
\text { (Kcal) }\end{array}$ & 385 & 353 & 336 & 309 & 332 & 305 & 650 & 327 \\
\hline Fat (g) & 2.3 & 3 & 2.8 & 1.4 & 3.6 & 3 & 50 & 2.8 \\
\hline
\end{tabular}

Table.3 Economics and Cost Analysis (Rs.)

\begin{tabular}{|l|c|c|c|c|c|c|c|c|}
\hline Particulars & $\begin{array}{c}\text { Millet } \\
\text { Health mix }\end{array}$ & $\begin{array}{c}\text { Chapathi } \\
\text { flour }\end{array}$ & $\begin{array}{c}\text { Adai } \\
\text { mix }\end{array}$ & $\begin{array}{c}\text { Idiyappam/ } \\
\text { Kozhu } \\
\text { kattai mix }\end{array}$ & $\begin{array}{c}\text { Uppuma } \\
\text { mix }\end{array}$ & $\begin{array}{c}\text { Murukku } \\
\text { mix }\end{array}$ & $\begin{array}{c}\text { Millets } \\
\text { cookies }\end{array}$ & $\begin{array}{c}\text { Iddli/Dosai } \\
\text { Mix }\end{array}$ \\
\hline $\begin{array}{l}\text { Production } \\
\text { cost }\end{array}$ & 130 & 100 & 150 & 90 & 90 & 90 & 110 & 100 \\
\hline Sale price & 250 & 200 & 240 & 200 & 200 & 200 & 250 & 200 \\
\hline Net return & 120 & 100 & 90 & 110 & 110 & 110 & 140 & 100 \\
\hline $\begin{array}{l}\text { Cost Benefit } \\
\text { Ratio }\end{array}$ & $\mathbf{1 : 1 . 9}$ & $\mathbf{1 : 2 . 0}$ & $\mathbf{1 : 1 . 9}$ & $\mathbf{1 : 2 . 2}$ & $\mathbf{1 : 2 . 2}$ & $\mathbf{1 : 2 . 2}$ & $\mathbf{1 : 2 . 3}$ & $\mathbf{1 : 2 . 0}$ \\
\hline
\end{tabular}

Licensing, branding and marketing of the products

KVK assisted the group members to obtain fssai certificate for the developed product and they have opened saving Bank account in the nearby bank for the production and marketing of the product. SHG after training programme started marketing their products in their own area with the support of KVK in all technical 
assistance and now running their enterprise successfully with the minimum income of Rs.10,000/- each after all expenditure.

Therefore, it is concluded with value added strategies and appropriate processing technologies, the millet grains can find a place in the preparation of several value added and health food products, which may then result in high demand from large urban populations and non traditional millet users. Thus, entrepreneurship development helps in alleviating poverty when employment opportunities are created through new entrepreneurial venture start-up or the growth of existing ones. This eventually result in boosting social wealth through the emergence of new market, new industries, new institutional form, new technology and increase in income which result in enhanced living standards for the populace.

\section{References}

Ahmed Zafer U. and JulionCarign C.(2012) International Entrepreneurshiph in Lebanon, Global Business Review, Sage Publication, 13(1), 25-38.

Balasubramanium. S (2013) Processing of millets - Lead Paper, Conference: National Seminar on Recent Advances in processing, utilization and nutritional impact of small millets, At I, 1-14, Volume: I, 1-14.

Fatoki, O. (2014). The financing options for new small and medium enterprises in South Africa. Mediterranean Journal of Social Sciences, 5(20), 748

Geetamma K. and Bulla, B. (2013). Golden Research Thoughts.

Global Entrepreneurship Monitor. (2007). 2006 Report on Women and Entrepreneurship. Centre for Women Leadership.: Babson.

Mamatha Rani R, Chavan UD, Kotecha PM and Lande SB Preparation and storage study of millet puttu, International Journal of Chemical Studies 2019; 7(3): 4453-4457, IJCS 2019; 7(3): 4453-4457

Mathanghi SK, Sudha K. Functional and phytochemical properties of finger millet (Eleusine coracana L.) for health. International Journal of Pharmaceutical, Chemical and Biological Sciences. 2012; 2(4):431438.

Mohamed TK, Issoufou A, Zhou H. Antioxidant activity of fractionated foxtail millet protein hydrolysate. International Food Research Journal. 2012; 19(1): 207-213.

Okpala, K.E. (2012). Venture capital and the emergence and development of entrepreneurship: A focus on employment generation and poverty alleviation in Lagos state. International Business and Management, 5(2), Pp:134-141.

Patankar.V and Metha N.K (2014) A Literature Review on Entrepreneurial Development and its antecedents, Conference: 3rd Annual Commerce Convention on Leveraging Business: Discovering New Horizons, At School of Economics, New Delhi.

Pradhan R. and Nath P, (2012). "Perception of Entrepreneurial Orientation and Emotional Intelligence: A Study on India's Future Techno-Managers" Global Business Review, Sage Publications, Vol. 13(1) pp. 89-108.

Pradhanand Nath, (2012), "Perception of Entrepreneurial Orientation and Emotional Intelligence: A study on India's Future Techno-Managers" Global Business Review, sage Publications, Vol 13(1) pp 89

Radhan R. andNath P, (2012). "Perception of Entrepreneurial Orientation and Emotional Intelligence: A Study on India's Future Techno-Managers" 
Global Business Review, Sage Publications, Vol. 13(1) pp. 89-108.

Seema B.R, Sudheer K.P, Ranasalavan, Vimithat and Sankalpak B (2016), Advances in Life Sciences, 5 (17), pp 6660-6662
UNESCAP (United Nations Economic and Social Commission for Asia and Pacific). (2012). Policy Guidebook for SME Development in Asia and the Pacific.Bangkok. United Nations.

\section{How to cite this article:}

Vimalarani, M. and Nisha, P.R.. 2020. Impact of Entrepreneurship Development Programme on Value addition of Millets Products for the Higher Income Generation of SHG. Int.J.Curr.Microbiol.App.Sci. 9(07): 10-16. doi: https://doi.org/10.20546/ijcmas.2020.907.002 